\title{
References:
}

1. Білозерська Л. П. Термінологія та переклад / Л. П. Білозерська, Н. В. Возненко, С. В. Радецька. Вінниця : Нова Книга. 2010. 232 с.

2. Буянова Л. Ю. Термин как единица логоса. Москва : ФЛИНТА. 2012. $224 \mathrm{c}$.

3. Карабан В.I. Переклад англомовної наукової i технічної літератури. Граматичні труднощі, лексичні, термінологічні та жанровостилістичні проблеми. Вінниця. 2004. 576 с.

4. L'Homme, M. What is a term? Lexical Semantics for Terminology. Netherlands: Amsterdam: Benjamins Publishing Company, 2020. Pp. 55-78.

DOI https://doi.org/10.30525/978-9934-26-110-7-65

\section{ВИКОРИСТАННЯ ЛЕКСИКО-ГРАМАТИЧНИХ ТРАНСФОРМАЦІЙ ПРИ ПЕРЕКЛАДІ НІМЕЦЬКИХ КОМПОЗИТІВ УКРАЇНСЬКОЮ МОВОЮ}

\author{
Редчиць Т. В. \\ кандидат філологічних наук, \\ дочент кафедри прикладної лінгвістики та перекладу \\ Черкаський державний технологічний університет \\ м. Черкаси, Украӥна
}

Словотвір є основним способом поповнення словникового складу німецької мови. Відсутність словникових відповідників для великої кількості складних слів вимагає докладного аналізу їх перекладу на українську мову та призводить до необхідності дослідження способів передачі композитів на українську мову.

Особливість словотвору німецької мови дала поштовх до комплексного дослідження науковцями цієї галузі науки, оскільки кожна мова має свою унікальну структуру та певні особливості. Характерна особливість німецької мови, що відрізняе ії від інших мов - це велика кількість складних слів.

Питанням словотвору німецької мови займалися такі лінгвісти, як К. Райс, Т. Шіппан, В. Фляйшер, М. Д. Степанова, О. О. Селіванова, Л. А. Ковбасюк, Т. Ф. Сфремова, Г. І. Артемчук, Ш. Р. Басиров, та інші.

Одним 3 найбільш продуктивних способів збагачення словникового фонду мови вважається деривація. Деривація займається вивченням компонентів, з яких складаються складні чи похідні слова, досліджує 
структуру та закономірності виникнення нових лексичних одиниць у мові.

Словоскладання або (Zusammensetzung) вважається найпродуктивнішим та найпоширенішим словотвірним типом німецької мови, тоді як для української він зовсім непродуктивний. Цей тип словотвору є одним 3 джерел розвитку й поповнення словникового складу за рахунок наявного арсеналу функційно-структурних одиниць [2, с. 427].

Для позначення складного слова дослідники-германісти нерідко використовують термін «композит» [4, с. 308], оскільки він характеризується ширшим значенням, але вітчизняними дослідниками більш уживаний термін «складне слово». Композити (лат. compositus складений з частин) у вузькому сенсі - це складні слова, що утворені за допомогою складання основ або кількох слів; у широкому сенсі - це особливий тип лінгвістичного знака, який представлений у лексичних системах типологічно різних мов, що $є$ виявом дії закону семантичної компресії синтаксичних одиниць [3, с. 7].

Композити стоять на межі семантики і ономастики, тому передача словоскладних конструкцій німецької мови засобами іншої мови потребує від перекладача особливих зусиль.

Проблемою перекладу композитів українською мовою прямо або опосередковано займалися такі українські мовознавці як В. В. Коптілов, О. Д. Огуй, Л. А. Ковбасюк, А. В. Шелудько та ін. Вченими були досліджені структурні, морфологічні, семантичні особливості утворення складних слів, їх функціонування та переклад у різних стилях мови.

Переклад німецьких словотворчих конструкцій на українську мову викликає масу труднощів, обумовлених системними особливостями обох мов. Але головна проблема при перекладі полягає в тому, що складні слова містять в собі зміст і сенс тексту: декодування їх значення не викликає труднощів в тому випадку, якщо існує достатньо відомостей про предмет і про ситуацію [1, с. 221]. Р.Г. Гатауллін акцентує увагу на тому, що для правильного перекладу словотворчих конструкцій необхідні: 1) знання мови, 2) фонові знання, які не завжди можна отримати безпосередньо з тексту, 3) культурно-специфічні, соціокультурні (історичні, економічні, політичні та інші знання) [1, с. 226].

При перекладі німецьких композитів на українську мову потрібно враховувати їх словотвірні моделі, ступінь узуальності / оказиональності. Також, перекладаючи німецькі композити на українську мову не можна забувати про їх багатозначність, коли переклад можливий лише на основі певного контексту. 
Використання перекладацьких трансформацій при перекладі складних слів обумовлено неможливістю їх адекватної передачі за допомогою дослівного перекладу. Трансформаційний переклад полягає в перетворенні внутрішньої форми слова або ж iї повної заміни для адекватної передачі змісту висловлювання. Завдання перекладача - вміло застосувати різні перекладацькі трансформації для того, щоб текст перекладу адекватно передавав усю інформацію, укладену в тексті оригіналу, з дотриманням відповідних мовних норм. У свою чергу вибір шляху перекладу залежить від кількох передумов: від характеру тексту; від значимості лексики в контексті; від характеру самої лексики, іії місця в лексичних системах мови перекладу і мови оригіналу; від самих мов їх словотворчих можливостей, літературної та мовної традиції.

Виокремлюють такі види композитів: іменникові композити, прикметникові складні слова та дієслівні сполуки.

Переклад німецьких складних іменників характеризується тим, що переважну їх більшість становлять означальні лексичні одиниці 3 субстантивним першим компонентом, який визначає другий. Тому такі композити перекладаються зазвичай словосполученням «прикметник + іменник». Значення першого субстантивного компонента німецького складного іменника перекладається на українську мову відносним прикметником [3, с. 125-130].

Аналіз перекладацьких трансформацій при перекладі складних іменників демонструє переважну кількість граматичних трансформації в публіцистичних та науково-технічних текстах, проте для художніх текстів більш характерним є вживання «змішаних трансформацій», де відбувається одночасно граматична, лексична та семантична трансформація тексту.

Наприклад: Kettenspannbolzen - прогонич для натягування ланцюга (за відсутності словникового відповідника частково використовується калькування 3 елементами смислового узгодження); autobiografische Spurensuche - книга, присвячена пошуку слідів своєї родини (додавання слів, смислове узгодження); Startschuss im September 2012 - офіційно проєкт стартував у вересні 2012 (додавання слів у структуру речення). Для передачі структурних екзотизмів також застосовується здебільшого експлікація, наприклад: Gelegenheitsraucher - людина, що курить не постійно, а принагідно; die Selbstverachtung - заздрість і презирство до самого себе.

Складні дієслівні сполучення передають на українську мову за допомогою використання перекладацької заміни або вилучення, 
та через використання атрибутивних, дієслівних або іменникових словосполучень.

Переклад складних прикметників передбачає різні варіанти їх передачі. Наприклад: rubinfarben - рубіновий (вилучення компоненту слова у випадку другорядності вираженої ознаки); rechteckige Retroautos - незграбні ретроавтомобілі (смислове узгодження); panzerbrechendes Wuchtgeschoss - спеціальний протитанковий бронебійний снаряд (застосовано прийом прийом контекстуальної заміни та додавання лексичної одиниці); güterbezogene Sanktionen - санкції, що стосуються окремих видів товарів (описовий переклад складного прикметника). Перед перекладачем постає непроста задача вибору оптимального еквівалента, який буде представлений окремим словом, словосполученням, або, навіть, реченням.

\section{Література:}

1. Гатауллин Р.Г. Стилистические аспекты немецкого словообразования (на примере сложных и производных существительных и их соответствий в русском языке) : дис. ... д-ра филол. наук: 10.02.04. Галле, 1997. $268 \mathrm{c}$.

2. Карпюк В. А. Особливості типології словоскладання у контексті неології сучасної німецької мови. Науковий вісник Волинського начіонального університету ім. Лесі Украӥнки. «Філологічні науки. Мовознавство» - Луцьк: Вид-во ВНУ ім. Лесі Українки, 2010. №. 8. C. 427-431.

3. Ковбасюк Л. А. Субстантивні композити сучасної німецької мови у міжкультурній комунікації: специфіка перекладу. Інформаційні технології в освіті. 2009. № 10. С. 125-130.

4. Peter von Polenz: Deutsche Sprachgeschichte vom Spätmittelalter bis zur Gegenwart/17. und 18. Jahrhundert. - De Gruyter. 2013. 603 S. 